\title{
Wool and grain dusts stimulate TNF secretion by alveolar macrophages in vitro
}

\author{
D M Brown, K Donaldson
}

\begin{abstract}
Objective-The aim of the study was to investigate the ability of two organic dusts, wool and grain, and their soluble leachates to stimulate secretion of tumour necrosis factor (TNF) by rat alveolar macrophages with special reference to the role of lipopolysaccharide (LPS).
\end{abstract}

Methods-Rat alveolar macrophages were isolated by bronchoalveolar lavage (BAL) and treated in vitro with whole dust, dust leachates, and a standard LPS preparation. TNF production was measured in supernatants with the $\mathbf{L 9 2 9}$ cell line bioassay .

Results-Both wool and grain dust samples were capable of stimulating TNF release from rat alveolar macrophages in a dose-dependent manner. The standard LPS preparation caused a dose-dependent secretion of TNF. Leachates prepared from the dusts contained LPS and also caused TNF release but leachable LPS could not account for the TNF release and it was clear that non-LPS leachable activity was present in the grain dust and that wool dust particles themselves were capable of causing release of TNF. The role of LPS in wool dust leachates was further investigated by treating peritoneal macrophages from two strains of mice, LPS responders (C3H) and LPS non-responders (C3H/HEJ), with LPS. The non-responder mouse macrophages produced very low concentrations of TNF in response to the wool dust leachates compared with the responders.

Conclusions-LPS and other unidentified leachable substances present on the surface of grain dust, and to a lesser extent on wool dust, are a trigger for TNF release by lung macrophages. Wool dust particles themselves stimulate TNF. TNF release from macrophages could contribute to enhancement of inflammatory responses and symptoms of bronchitis and breathlessness in workers exposed to organic dusts such as wool and grain.

(Occup Environ Med 1996;53:387-393)

Keywords: organic dust; macrophage; tumour necrosis factor; endotoxin; bronchitis

Tumour necrosis factor (TNF) is a proinflammatory cytokine produced by macrophages or monocytic phagocytes in response to various stimuli. ${ }^{1-3}$ In the non-stimulated state, alveolar macrophages do not secrete TNF. However, triggers of macrophage activation including the phagocytosis of organic and inorganic dusts, phorbol esters and bacterial lipopolysaccharide (endotoxin) (LPS) stimulate secretion of TNF both in vivo and in vitro. ${ }^{45}$ The effects of TNF on other cells are wide ranging, and as well as causing differentiation of myeloid cell lines and growth of B-lymphocytes, TNF also stimulates mitogenesis of lung fibroblasts. ${ }^{126}$ An important proinflammatory action of TNF and other cytokines is the activation of cell adhesion molecules, such as the leukocyte integrins (CD1 1a b c/CD18), and intercellular adhesion molecule-1 (ICAM-1). ${ }^{78}$ Endothelial cell adhesion molecules are also activated by TNF. ${ }^{910}$ The increased adhesivity of the endothelial cell adhesion molecules enhances neutrophil adherence, an essential first step in the migration of leucocytes from the microvasculature into the tissues to sites of inflammation.

Organic dusts include a range of airborne material comprising plant components, pollens, and spores. Dust which is deposited in the alveolar region of the lung may cause activation of complement, which is present in the alveolar lining fluid, with generation of leucocyte chemotaxins. ${ }^{11}$ These events have previously been shown with extracts of organic dusts, endotoxin, and activation of serum. ${ }^{12} 13$ In the lung after deposition of organic dust, a sequence of events may be envisaged where alveolar macrophages become activated, secrete inflammatory mediators, and act in a synergistic manner with activated complement fragments to enhance inflammation.

In a previous study, a relation was shown between the airborne mass concentration of wool dust and symptoms of airway irritation in exposed workers in wool textile mills in the north of England. ${ }^{14}{ }^{15}$ Dusts collected from the air of wool mills were shown to be contaminated with bacterial endotoxin and to be able to produce an acute inflammatory response when instilled into the lungs of rats ${ }^{16}$ but were not notably toxic to macrophages and epithelial cells. ${ }^{17}$ Endotoxin has been implicated in symptoms of byssinosis in workers in a wool carpet factory in Turkey. ${ }^{18}$ The wool dust collected from the air of English wool mills was also capable of up regulating homotypic adhesion of alveolar macrophages ${ }^{19}$ by activation of LFA-1/ICAM-1 ligand-receptor binding. Wool dust also caused granulomatous lesions after instillation into the lungs of rats. ${ }^{20}$ In this study, we have examined the ability of 
inspirable wool dusts, sieved grain dust, and leachates from the dusts to produce TNF secretion by rat alveolar macrophages in vitro.

\section{Materials and methods \\ ANIMALS \\ Male SPF HAN rats (Charles River, Margate, UK) were used throughout.}

\section{COLLECTION OF WOOL DUSTS}

Dusts were collected from two wool process mills in the north of England designated $S$ (start) and $\mathrm{M}$ (middle) which represented opening-blending and combing processes respectively. A series of six Institute of Occupational Medicine static inspirable dust samplers, ${ }^{21}$ were placed at each site in the dustiest zones. Samplers were operated for a full work shift and an inspirable sample of dust was collected on Gelman GLA filters with a $5 \mu \mathrm{m}$ pore size (Gelman Hawksley, Northampton). Dust was removed from filters with a soft brush. Dust from each mill was pooled into a tube, weighed, and mechanically rotated for 24 hours to ensure mixing and these samples were stored at $-20^{\circ} \mathrm{C}$ until required. The wool dust used for the study was inspirable - that is, dust which could pass into the upper airways. This fraction of dust also included a large proportion of respirable dust which could penetrate to the terminal bronchioles and proximal lung parenchyma.

\section{COLLECTION OF GRAIN DUST}

Samples of dust were collected from the ledges of a barn which stored wheat and barley. The dust was sieved through a $200 \mu \mathrm{m}$ mesh, followed by a $45 \mu \mathrm{m}$ mesh, by shaking mechanically for 30 minutes. The dust so obtained from this process and used in all subsequent assays was less than $45 \mu \mathrm{m}$ diameter and included a substantial proportion of respirable dust.

\section{PREPARATION OF WOOL AND GRAIN DUSTS AND PREPARATION OF LEACHATES}

Separate samples of leachate (materials leached from organic dust into aqueous solution) were prepared by mixing wool dust and grain dust in phosphate buffered saline (PBS) at a concentration of $5 \mathrm{mg} / \mathrm{ml}$ at room temperature for 24 hours. Solutions were then centrifuged at 3000 $\mathrm{rpm}$ for 15 minutes to remove large fragments and then finally filtered through $0.22 \mu \mathrm{m}$ filters to sterilise the leachates. Half of each sample was then depleted of endotoxin by passing down Polymyxin B columns (Flow, High Wycombe, Bucks) according to the manufacturer's instructions.

MEASUREMENTS OF THE ENDOTOXIN CONTENT OF WOOL AND GRAIN DUST LEACHATES

The "Coatest" (ICN, Flow, High Wycombe, Bucks) Limulus amoebocyte lysis (LAL) based spectrophotometric assay was used to assess the endotoxin content of the wool and grain leachates.

BRONCHOALVEOLAR LAVAGE

Animals were killed with a single intraperi- toneal injection of Nembutal, the thoracic cavity was opened and the lungs were cannulated and removed. The lungs were then sequentially lavaged with four $8 \mathrm{ml}$ aliquots of saline at $37^{\circ} \mathrm{C}$ and pooled into a single tube. Cells were centrifuged at $1000 \mathrm{rpm}$ in a refrigerated bench centrifuge for 10 minutes, and resuspended in F-10 medium (Gibco, Paisley) containing 0.2\% bovine serum albumin (BSA) (Fraction V Sigma, Poole, Dorset) and kept on ice. Total cell numbers were evaluated and cytocentrifuge smears, which were stained with MayGrunwald Giemsa, were prepared. One hundred cells per cytospin were evaluated to obtain a differential cell count. Cells were adjusted to a concentration of $1 \times 10^{6} \mathrm{cells} / \mathrm{ml}$ in medium containing the dusts at various concentrations and $1 \mathrm{ml}$ was pipetted into wells of a 24 well plate (Greiner Labortechnik, Cam, Dursley). After incubation for one hour to allow adherence the dusts were added, suspended in the same medium. Macrophages were incubated with dust overnight ( 16 hours) at $37^{\circ} \mathrm{C}$ in $5 \%$ $\mathrm{CO}_{2}$ after which the medium was removed and centrifuged at $3000 \mathrm{rpm}$ for 15 minutes to remove dust particles. The supernatants were stored at $-70^{\circ} \mathrm{C}$ until assay for TNF.

PREPARATION OF SUPERNATANTS FROM C3H AND C3H/HEJ MOUSE PERTTONEAL MACROPHAGES

A separate group of dust leachates was prepared for use in the TNF assay in F-10 medium (Gibco, Paisley) containing $0 \cdot 2 \%$ BSA, (Flow Labs, High Wycombe). This medium contained negligible amounts of LPS, as defined by the manufacturer's assay.

Macrophages from $\mathrm{C} 3 \mathrm{H} / \mathrm{HEJ}$ mice are unresponsive to the effect of LPS, ${ }^{22}$ and the related C3H mice respond normally. Peritoneal exudate cells were treated with dust leachates to prepare supernatants, which were then assessed for their TNF content. This allowed the involvement of endotoxin present in the leachates to be estimated.

Mice were treated with a single intraperitoneal injection of $0.5 \mathrm{ml}$ of $1 \%$ thioglycollate broth. Three days later, these mice were killed with ether, and the peritoneal cavity was lavaged with $3 \times 2 \mathrm{ml}$ volumes of PBS containing heparin at a final concentration of 100 $\mathrm{U} / \mathrm{ml}$. Lavage fluid was centrifuged at 1000 rpm for five minutes, resuspended in F-10 $+0.2 \% \mathrm{BSA}$ and cells were counted. Cells were adjusted to $1 \times 10^{6} \mathrm{cells} / \mathrm{ml}$ and $1 \mathrm{ml}$ added to each well in 24 well plates which were incubated at $37^{\circ} \mathrm{C}$ for one hour. The medium was then removed, adherent cells were washed twice with PBS, and the dust leachates (prepared in $\mathrm{F}-10+0.2 \% \mathrm{BSA}$ ) added to the wells. Plates were incubated at $37^{\circ} \mathrm{C}$ overnight, supernatants removed, spun at $3000 \mathrm{rpm}$ for 15 minutes, and stored at $-70^{\circ} \mathrm{C}$ until required.

\section{ENDOTOXIN DOSE RESPONSE}

Endotoxin from Escherichia coli serotype 011:B4 (Sigma, Poole, Dorset) was made up to $1 \mathrm{mg} / \mathrm{ml}$ in $\mathrm{PBS}$, and stored at $-70^{\circ} \mathrm{C}$. Some experiments comprised treating alveolar macrophages with LPS at various concentrations. Supernatants from leachate treated 
macrophages were prepared by treating adherent macrophages with $1 \mathrm{ml}$ of leachate and endotoxin depleted leachate.

\section{TNF ASSAY}

This assay relies on the fact that cells of the mouse fibroblast cell line L929 are specifically susceptible to the lethal effects of TNF if the cells are pretreated with the protein synthesis inhibitor actinomycin D. After treatment with TNF, the surviving cells are stained and the absorbence of stain is taken as a quantitative measure of survival, from which the amount of cell death can be calculated. The specificity of the assay for TNF in rat macrophage supernatants has been confirmed with specific antibody against TNF and is calibrated with recombinant TNF. ${ }^{23}$

The L929 cells were removed from continuous culture with $0 \cdot 1 \%$ trypsin-EDTA (Gibco, Paisley, Scotland), and resuspended in minimal essential medium (Gibco, Paisley), containing $10 \%$ heat inactivated foetal calf serum, penicillin, and streptomycin (complete medium). Cells were adjusted to $3 \times 10^{5}$ cells $/ \mathrm{ml}$ in complete medium, and $100 \mu \mathrm{l}$ was added to each well in 96 well plates (Greiner Labortechnik, Cam, Dursley), which were incubated at $37^{\circ} \mathrm{C}$ overnight in a humidified atmosphere of $5 \% \mathrm{CO}_{2}$.

On day 2 the medium in each well was replaced with minimal essential medium containing $5 \%$ fetal calf serum, $1 \mu \mathrm{g} / \mathrm{ml}$ actinomycin D (Sigma, Poole, Dorset), without antibiotics. The top row of each plate received an additional $50 \mu \mathrm{l}$ of medium containing actinomycin D at a concentration of $2 \mu \mathrm{g} / \mathrm{ml}$. The bottom row of each plate served as the control wells (six wells) and the remaining set of six wells were used as blanks to set the spectrophotometer.

The top row of each plate received a final $50 \mu \mathrm{l}$ of test supernatant, each supernatant being measured in triplicate. A multichannel pipette was used to double dilute $100 \mu$ from the top row of wells down the plate, ending before the bottom control wells. The final 100 $\mu \mathrm{l}$ of medium was discarded. One set of wells contained a TNF standard (National Institute for Biological Standards and Control, Potters Bar, Hertfordshire) at a concentration of 100 $\mathrm{U} / \mathrm{ml}$. Plates were then incubated for a further 24 hours.

On day 3, the medium and supernatant in each well was removed and replaced with 50 $\mu \mathrm{l}$ of $1 \%$ crystal violet stain in $20 \%$ methanol for two minutes. Each plate was washed with tap water and allowed to dry, after which each well received $50 \mu \mathrm{l}$ of $20 \%$ acetic acid to make soluble the stained cells. Any bubbles were removed and plates were read at $540 \mathrm{~nm}$ with an automatic plate reader interfaced with a personal computer.

\section{TNF CALCULATIONS}

The mean optical density (OD) was calculated for each sample dilution as a percentage of the untreated control. The sample dilutions were converted to $\log _{e}$ values and regressions performed with the sample OD\% $v \log _{e}$ dilution.
The $\log _{e}$ dilution value that gave an OD of $50 \%$ of the control cells was calculated with the equation:

$$
\begin{gathered}
\text { OD } \%=\text { intercept }+ \text { slope } \times \log _{e} \text { dilution } \\
\log _{e} \text { dilution }(50 \%)=(50-A) / B
\end{gathered}
$$

The number of units of TNF was finally calculated from the TNF standard, which was included in each experiment. As in the sample wells, the OD, which was $50 \%$ of the OD of the control wells, was obtained and related back to the known concentration of TNF in the standard.

\section{STATISTICAL ANALYSIS}

Data were examined with analysis of variance.

\section{Results}

(1) TNF PRODUCTION BY RAT ALVEOLAR MACROPHAGES TREATED WITH WOOL AND GRAIN DUSTS IN VITRO

Alveolar macrophages from untreated rats were obtained by $\mathrm{BAL}$ and treated in vitro with whole dust, dust leachates, leachates treated with polymyxin, and a standard endotoxin preparation. The supernatants so produced were estimated for TNF content with the L929 assay. The data in fig 1 show TNF production by macrophages treated with whole wool and grain dust samples.

This figure shows that spontaneous production of TNF in untreated macrophages was virtually nil. In the dust treated cells, at a concentration of $50 \mu \mathrm{g} / \mathrm{ml}$ dust, wool dust S produced about $750 \mathrm{UTNF} / \mathrm{ml}$, dust $M 650 \mathrm{U}$ $\mathrm{TNF} / \mathrm{ml}$, and grain $550 \mathrm{U} \mathrm{TNF} / \mathrm{ml}$. At a concentration of $100 \mu \mathrm{g} / \mathrm{ml}$ the TNF production was about $1750 \mathrm{U} \mathrm{TNF} / \mathrm{ml}$ in all three cases.

Analysis of variance showed that there was no difference between dusts $(F=0.274$; $P>0.05$ ). There was, however, a significant effect of dust concentration $(F=55.40$; $P<0.01$ ), but no significant treatment-dose interaction $(F=1.080 ; P>0.05)$.

Both wool and grain dusts are thus potent triggers of TNF production, there was a dose dependent effect of dust and, on an equal mass basis, the dusts did not differ in their ability to stimulate secretion of TNF.



Figure 1 TNF production by rat alveolar macrophages untreated or treated in vitro with wool dusts $S$ and $M$, and grain dust. The data are the mean (SEM) of the number of units of TNF contained in supernatants prepared on three separate occasions. 
Figure 2 TNF production by rat alveolar macrophages treated in vitro with wool dust leachate $S$ and $M$, and grain dust leachate. The graph also shows the effect of endotoxin depletion on TNF production. The data are the mean (SEM) of the number of units of TNF in supernatant prepared on three separate occasions.

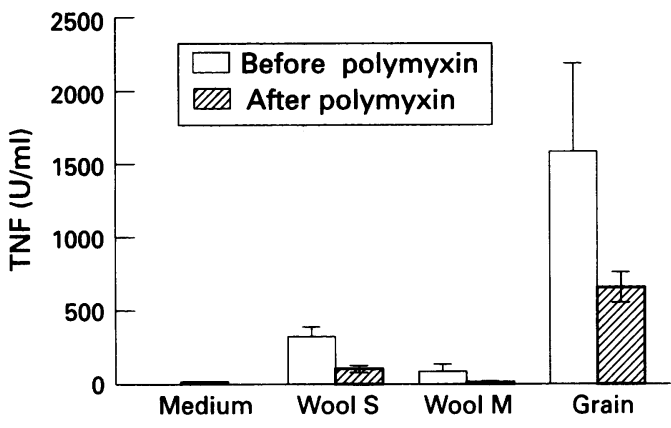

The endotoxin content of wool and grain dust leachates before and after depletion with a polymyxin column

\begin{tabular}{lll}
\hline & \multicolumn{2}{l}{ Endotoxin $(\mathrm{ng} / \mathrm{ml})$} \\
\cline { 2 - 3 } Leachate & Before column & After column \\
\hline Wools S & 21.99 & $0 \cdot 14$ \\
Wool M & 19.76 & $0 \cdot 16$ \\
Grain & 14.99 & $0 \cdot 14$ \\
LPS & 22.45 & $0 \cdot 13$ \\
\hline
\end{tabular}

(2) THE EFFECT OF DUST LEACHATES ON TNF PRODUCTION BY RAT ALVEOLAR MACROPHAGES The possible role of endotoxin associated with dust in causing release of TNF by alveolar macrophages treated with dust was tested by dust leachate with or without depletion of endotoxin on polymyxin columns.

Figure 2, which summarises these results, shows that untreated macrophages produced no TNF. Wool dust leachates stimulated a modest increase in TNF release, wool $S$ leachate producing about twice as much (about $300 \mathrm{UTNF} / \mathrm{ml}$ ) as leachate $\mathrm{M}$. The grain leachate, stimulated substantially more TNF secretion than wool leachates, in the range of $1500 \mathrm{UTNF} / \mathrm{ml}$. Thus, in this assay system, soluble material from grain was more potent than wool in stimulating TNF production by macrophages, and there was a significant effect of leachate treatment $(F=81.65$; $P<0.001$ ).

A striking effect of LPS was seen in supernatants which had been depleted of endotoxin by passing through a polymyxin column (table). Supernatant depleted of endotoxin released substantially less TNF from alveolar macrophages than untreated leachates (fig 2). Analysis of variance showed in these results that there was a significant effect of depletion

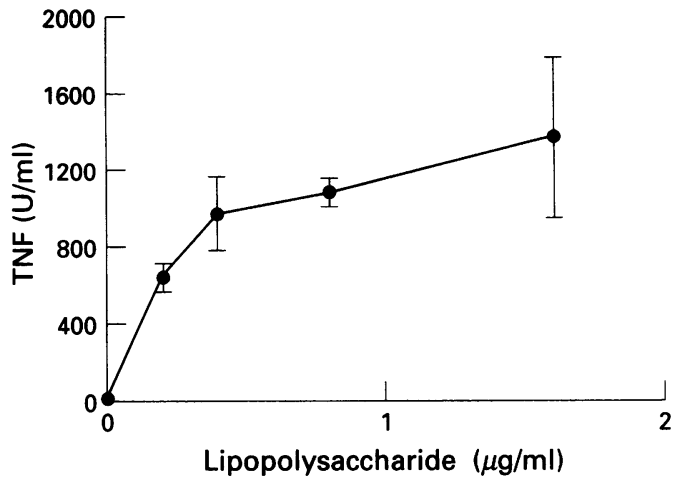

Figure 3 TNF production by rat alveolar macrophages treated in vitro with various concentrations of

lipopolysaccharide. The data are the mean (SEM) of the number of units of TNF in supernatant prepared on three separate occasions.

of LPS by polymyxin $(F=17.08 ; P<0.05)$. There was no significant interaction between different leachates and polymyxin $(F=0.62$; $P>0.05)$ indicating that the contribution of LPS was consistent between the different leachates.

The results suggest that a substantial part of the TNF production was due to the presence of bacterial endotoxin.

\section{(3) EFFECT OF PURE ENDOTOXIN ON TNF}

PRODUCTION BY RAT ALVEOLAR MACROPHAGES Production of TNF by macrophages treated in vitro with a commercially available endotoxin preparation was assessed to further confirm the role of LPS (fig 3).

There was virtually no TNF produced in only the medium, but this increased to $633 \mathrm{U}$ $\mathrm{TNF} / \mathrm{ml}$ at $200 \mathrm{ng} / \mathrm{ml}$, the lowest dose used; the response only about doubled when the concentration increased to $800 \mathrm{ng} / \mathrm{ml}$. Thereafter there was a very shallow increase with dose (data not shown).

\section{(4) EFFECT OF DUST LEACHATES AND} DEPLETED LEACHATES ON TNF PRODUCTION BY MACROPHAGES FROM C3H/HEJ MICE

Mice of the strain $\mathrm{C} 3 \mathrm{H} / \mathrm{HEJ}$ do not respond to endotoxin, $\mathrm{C} 3 \mathrm{H}$ mice respond normally to endotoxin. Peritoneal macrophages from both these strains were treated with dust leachates and endotoxin depleted leachates to compare the role of endotoxin in TNF secretion.
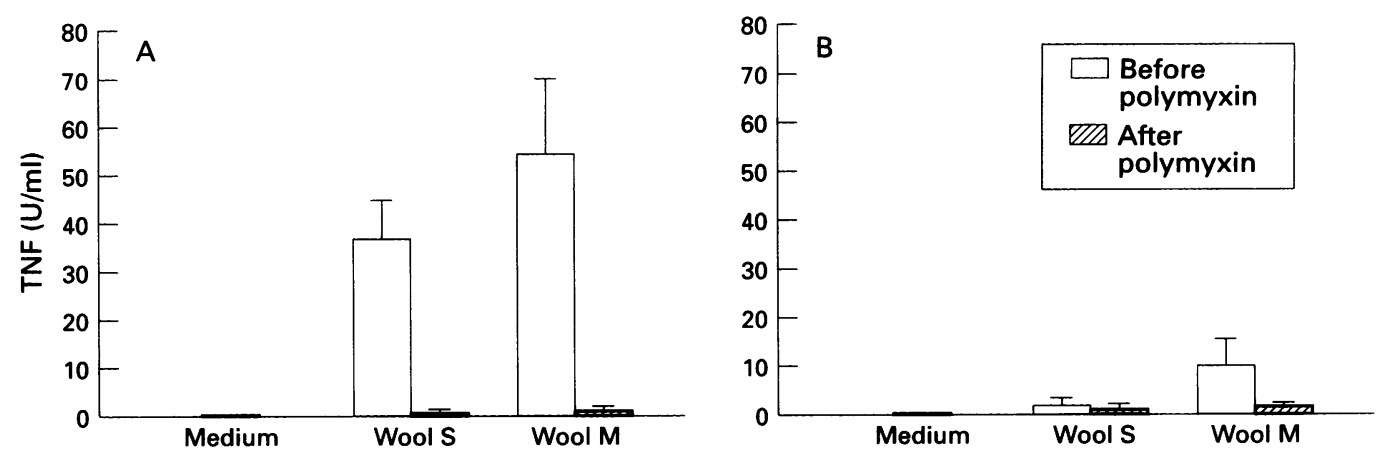

Figure $4 T N F$ production by $C 3 H$ ( $A$ normal endotoxin responders) and $C 3 H / H E \mathcal{H}$ ( $B$ endotoxin non-responders) peritoneal macrophages treated with dust leachates and leachates depleted of endotoxin with polymyxin. The data are the mean (SEM) of the number of units of TNF in supernatant prepared on three separate occasions. 
Figure 4 summarises these effects and shows that dust leachates can trigger the release of TNF from normal responder $\mathrm{C} 3 \mathrm{H}$ mice, as is found with rat alveolar macrophages, although the overall response was lower with rat cells. Removal of endotoxin caused a dramatic reduction in the TNF produced ( $35 \mathrm{U} \mathrm{TNF} / \mathrm{ml}$ reduced to $3 \mathrm{U} \mathrm{TNF} / \mathrm{ml}$ for leachate $\mathrm{S}$, and $55 \mathrm{U} \mathrm{TNF} / \mathrm{ml}$ reduced to 4 $\mathrm{U} \mathrm{TNF} / \mathrm{ml}$ for leachate $\mathrm{M}$ ). Grain leachate was not assessed because of the difficulty in preparing a sterile supernatant.

By contrast, in the non-responder $\mathrm{C} 3 \mathrm{H} /$ HEJ mouse peritoneal macrophages, very small amounts of TNF were produced, the maximum being $10 \mathrm{U} \mathrm{TNF} / \mathrm{ml}$ in untreated leachate $\mathrm{M}$, and about $3 \mathrm{UTNF} / \mathrm{ml}$ in untreated leachate $S$. Removal of endotoxin reduced these responses still further, to $2 \mathrm{U}$ $\mathrm{TNF} / \mathrm{ml}$ for both leachates.

After analysis of variance, there was a significant effect of treatment (medium $v$ leachate, $\mathrm{F}=15.89 ; \mathrm{P}<0.05)$, a significant effect of polymyxin $(F=57.70 ; P<0.05)$, and a significant difference between the two strains of mice $(F=80.43 ; P<0.05)$.

\section{Discussion}

Tumour necrosis factor is a member of the cytokine family of proteins which are secreted by macrophages, monocytes, and lymphocytes. ${ }^{724}$ Secretion is triggered by stimuli such as inflammation, infection or injury, and more specifically by other molecules such as interferon- $\gamma .{ }^{25}$ Microorganisms and viruses can also cause TNF production. ${ }^{4}$ One of the most potent triggers of TNF and other cytokines is the bacterial endotoxin (LPS). ${ }^{26}{ }^{27}$ Endotoxin has also been shown to be an activator of the complement system as well as a potent trigger in the immune system ${ }^{12}$ and a stimulator of low level chemotaxin release from macrophages. It was notable that in the Snella study, high doses of endotoxin, as found here, were associated with toxicity. ${ }^{28}$ The wool and grain dusts used in this study have been shown to be heavily contaminated with LPS, which was also present in aqueous leachates of the dusts.

Rat alveolar macrophages treated in vitro with wool and grain dusts caused significant amounts of TNF to be released in a dose dependent manner. Untreated (medium only) macrophages produced almost undetectable amounts of TNF. In keeping with these results, leachates of dust produced secretion of TNF in modest amounts.

Previous work where guinea pigs inhaled cotton dust which was contaminated with bacterial endotoxin, showed that TNF was produced in the lung only three hours after exposure. ${ }^{29}$ That study concluded that endotoxin was the main stimulus causing TNF secretion. Similarly, wool and grain dust depositing in the airways and alveolar region of the lung may potentially cause TNF release from macrophages and epithelial cells mediated mainly by LPS. Tumour necrosis factor may then cause inflammatory cell recruitment into the lung and may stimulate fibroblast proliferation. In a lung chronically exposed to respirable dust on a daily basis, this regular initiation of release of TNF could lead to chronic inflammation with predictable pathological sequelae. Although it is difficult to extrapolate from the acute high dose stimulation of TNF, shown here in vitro, and the chronic effects in someone inhaling dust, a clear role for TNF in the chronic effects of an inhaled dust has been shown. ${ }^{30}$ In that study quartz was shown to cause fibrosis (silicosis) in mice but this could be prevented by an antibody to TNF. We do not suggest that TNF is the only mediator that is likely to be involved in the pulmonary response to inhaled wool dust but the importance of TNF in promoting inflammation and leading to chronic lung disease $^{30}$ makes these findings of potential importance.

The role of endotoxin in the production of TNF was further examined with the use of leachates of dust which had been treated with polymyxin to remove LPS. The leachates were used to treat alveolar macrophages in vitro and the resulting supernatants were tested for TNF content. Grain and wool dust leachates had about the same amounts of LPS in them, as measured in the Limulus amoebocyte lysate assay. However, in the case of wool dust, the leachates had modest TNF stimulating activity which was lowered by polymixin treatment that removed the LPS, whereas grain dust leachate had significantly more TNF stimulating activity, which was only halved by removal of LPS in the polymixin column. This could be interpreted to mean that, as well as a substantial amount of contaminating LPS, another stimulant of TNF secretion is released from grain dust. We have no information on the identity of this material, which could be derived from the grain or contaminating micoorganisms. The fact that the whole wool and grain dusts had similar TNF stimulating activities suggests that the wool dust has an additional associated component that is not leachable but is stimulatory to macrophage secretion of TNF. This could be related to the biochemistry, or most likely to the fibrous shape, of the grain dust particles and deserves further study.

With reagent grade purified endotoxin, we were able to show that rat alveolar macrophages released substantial quantities of TNF in response to endotoxin. Additional confirmation of the partial role of endotoxin in TNF production by wool dust leachates was shown with mice which are non-sensitive to LPS. Mice of the $\mathrm{C} 3 \mathrm{H} / \mathrm{HEJ}$ strain have a genetic alteration which renders them non-responsive to LPS. The normal counterpart, $\mathrm{C} 3 \mathrm{H}$, responds normally. ${ }^{31}$ Experiments were carried out in which dust leachates and leachates treated with polymyxin to deplete endotoxin were used to trigger release of TNF from peritoneal macrophages from the two strains of mice. The results clearly showed that the nonresponder mouse macrophages produced very low concentrations of TNF compared with the normal responder mouse macrophages in 
response to leachates from wool dust. Removal of endotoxin resulted in even smaller amounts of TNF production by the cells. Unfortunately, due to contamination problems in the preparation of leachate, we were unable to repeat these studies with grain dust.

Tumour necrosis factor plays an important part in the inflammatory response and affects target cells in different ways. One of the main effects of TNF is that it can enhance neutrophil recruitment to the site of inflammation by activating adhesion molecules on the cell surface causing more cells to adhere to the endothelium of capillaries. The chemotactic ability of TNF for inflammatory neutrophils has been shown in vitro ${ }^{32}$ although a separate study showed that TNF could cause inhibition of neutrophil chemotaxis. ${ }^{33}$ These effects suggest that TNF has two roles in the chemotaxis of cells. Firstly, TNF can recruit neutrophils to inflammatory sites. Secondly, when cells arrive at this site, TNF acts in the opposite way, causing migration to be inhibited, and the cells to be held at the inflammatory site. The accumulation of neutrophils with increased phagocytic and bacteriocidal capabilities and with greater potential for release of proteinases, superoxide anion, and other molecules is clearly beneficial to efficient host defence. ${ }^{34}$ However, in the lungs of people inhaling the organic dusts used here, the same proinflammatory events can be envisaged to occur at sites of deposition in the airways and terminal bronchioles. In the long term these could lead to tissue damage and stimulation of mesenchymal cell secretion and proliferation.

Symptoms of bronchitis have been described in workers exposed to wool dust and in grain handlers. ${ }^{15} 35$ In obstructive lung disease, the role of TNF in mediating the inflammatory response and its consequences has been widely reported. ${ }^{36} 37$ Studies show that during exacerbations of chronic bronchitis there is an increase in the number of cells positive for TNF $\alpha$ in the bronchial mucosa. ${ }^{38}$ The data presented here suggest a possible role for LPS in causing TNF accumulation that could be a factor in bronchitis in these workers.

In a different study where an organic particle, yeast cell wall 1-3- $\beta$-D-glucan, was infused intravenously into rats, granulomas were produced in the lung. ${ }^{39}$ The presence of chemoattractant protein-1 (MCP-1) derived from monocytes is required for granuloma formation, ${ }^{39}$ and this can be induced by TNF and interleukin-1 (IL-1). Flory et $a l^{39}$ showed that infusion of antibodies against TNF and IL-1 considerably reduced the size of the granulomas and indicated that these cytokines played a regulatory part in the formation of granulomas produced by organic particles. The wool and grain dusts used in the present study were also capable of producing granulomas in rat lungs after intratracheal instillation. ${ }^{20}$ Although production of granulomas is very likely to be a result of the instillation mode of delivery, this provides indirect evidence for the role of TNF in the genesis of granulomas.

The implication of these findings and the results of the dust and leachate experiments, where TNF was produced by rat alveolar macrophages, indicate that the symptoms of bronchitis and breathlessness reported by workers exposed to organic dust may result from similar events in their lungs. These results would indicate that LPS, very likely originating from contaminating bacteria present on the dust surface, could be the trigger for release of TNF leading to the enhancement and maintenance of a chronic inflammatory response in people exposed to respirable organic dust on a daily occupational basis.

We thank Dr M Topping of the Health and Safety Executive for providing grain dust samples. This project was funded by the Health and Safety Executive.

1 Kelley J. Cytokines of the lung. Am Rev Respir Dis 1990 141:765-88.

2 Wakefield PE, James WD, Samaska CP, Meltzer MS. Tumor necrosis factor. $\mathcal{f}$ Am Acad Dermatol 1991;24: 675-85.

3 Matic M, Simon SR. Tumor necrosis factor release from lipopolysaccharide-stimulated human monocytes: lipopolysaccharide tolerance in vitro. Cytokine 1991;3: polysacchar

4 Bienhoff SE, Allen GK, Berg JN. Release of tumor necrosis factor-alpha from bovine alveolar macrophages stimulated with bovine respiratory viruses and bacterial endotoxins. Vet Immunol Immunopathol 1991;30:341-57.

5 De Rochemonteix-Galve B, Marchat-Amoruso B, Daye JM, Rylander R. Tumor necrosis factor and interleukin-1 activities in free lung cells after single and repeated inhalation of bacterial endotoxin. Infect Immun 1991; 59:3646-50.

6 Kovacs EJ. Fibrogenic cytokines: the role of immune mediators in the development of scar tissue. Immunol Today 1991;21:17-23.

7 Warren JS. Interleukins and tumor necrosis factor in inflammation. Crit Rev Clin Lab Sc 1990;28:37-59.

8 Webb DSA, Mostowski HS, Gerrard TL. Cytokineinduced enhancement of ICAM-1 expression results in increased vulnerability of tumor cells to monocyte-mediated lysis. $\mathcal{F}$ Immunol 1991;146:3682-6.

9 Luscinskas FW, Cybulsky MI, Kiely JM, Peckins CS, Davis VM, Gimbrone MA Jr. Cytokine-activated human endothelial monolayers support enhanced neutrophil transmigration via a mechanism involving both endothelial-leukocyte adhesion molecule-1 and intercellular adhesion molecule-1. F Immunol 1991;146:1617-25.

10 Pober JS, Gimbrone MA, Jr, Lapierre LA, Mendrick DL, Fiers W, Rothlein R, Springer TA. Overlapping patterns of activation of human endothelial cells by interleukin-1, tumor necrosis factor, and immune interferon. $\mathcal{F}$ Immuno 1986;137:1893-6.

11 Edwards JH, Wagner JC, Seal RM. Pulmonary responses to particulate materials capable of activating the alternative pathway of complement. Clin Allergy 1976;6:155.

12 Wilson MR, Sekul A, Ory R, Salvaggio JE, Lehrer SB. Activation of the alternative complement pathway by extracts of cotton dust. Clin Allergy 1980;10:303-8.

13 Olenchock SA, Mull JC, Major PC. Extracts of airborne grain dusts activate alternative and classical complement grain dusts activate alternative and cl
pathways. Ann Allergy 1980;44:23-8.

14 Love RG, Smith TA, Gurr D, Soutar CA, Scarisbrick DA, Seaton A. Respiratory and allergic symptoms in wool textile workers. $\mathrm{Br} \mathcal{F}$ Ind Med 1988;45:727-41.

15 Love RG, Muirhead M, Collins HPR, Soutar CA. The characteristics of respiratory ill health of wool textile workers. Br F Ind Med 1991;48:221-8.

16 Donaldson K, Brown GM, Brown DM, Slight J, Cullen RT, Love RG, Soutar CA. Inflammation in the lungs of rats after deposition of dust collected from the air of wool mills: the role of epithelial injury and complement activation. Br F Ind Med 1990;47:231-8.

17 Brown DM, Donaldson K. Injurious effects of wool and grain dusts on alveolar epithelial cells and macrophages grain dusts on alveolar epithelial cells a
in vitro. Br $\mathcal{F}$ Ind Med 1991;48:196-202.

18 Ozesmi Aslan H, Hillerdal G, Rylander R, Ozesmi C, Baris YI. Byssinosis in carpet weavers exposed to wool contaminated with endotoxin. Br f Ind Med 1987;44:479-83.

19 Brown DM, Dransfield I, Wetherill GZ, Donaldson K. LFA-1 and ICAM-1 in homotypic aggregation of rat alveolar macrophages: organic dust-mediated aggregation by a non-protein kinase $\mathrm{C}$-dependent pathway. $\mathrm{Am} \mathcal{F}$ Respir Cell Mol Biol 1993;9:205-12.

20 Brown DM, Donaldson K. Activity of wool mill dust in vitro and in vivo; cytotoxicity, cytokine production, lymph node stimulation and histopathology. Ann Occup Hyg 1994;38:887-94.

21 Mark D, Vincent JH, Gibson H, Lynch G. A new static sampler for airborne total dust in workplaces. Am Ind Hyg Assoc $\mathcal{F}$ 1985;46:127-33.

22 Rosenstreich DL, Vogel SN, Jacques AR, Wahl LM, Oppenheim J. Macrophage sensitivity to endotoxin: genetic control by a single codominant gene. $\mathcal{f}$ Immunol genetic control by a sin 
23 Donaldson K, Li X-Y, Dogra S, Miller BG, Brown GM. Asbetos-stimulated tumour necrosis factor release from alveolar macrophages depends on fibre length and opsonisation. $\mathcal{F}$ Pathol 1992;168:243-8.

24 Larrick JW, Kunkel SL. The role of tumor necrosis factor and interleukin-1 in the immunoinflammatory response. Pharmacol Res 1988;5:129-39.

25 Jones A. Tumor necrosis factor. Transfusion Science 1991; 12:67-73.

26 Beutler B, Krochin N, Milsark IW, Leudke C, Cerami A. Control of cachectin (tumor necrosis factor) synthesis: Control of cachectin (tumor necrosis factor) synthesis:
mechanisms of endotoxin resistance. Science 1986;232: mechanism

27 Feist W, Ulmer AJ, Musehold J, Brade H, Kusumoto S, Flad HD. Induction of tumor necrosis factoralpha release by lipopolysaccharide and defined lipopolysaccharide partial structures. Immunobiology 1989; 179:293.

28 Snella MC. Production of a neutrophil chemotactic factor by ebdotoxin-stimulated alveolar macrophages in vitro. Br f Exp Pathol 1986;67:801-7

29 Ryan LK, Karol MH. Release of tumor necrosis factor in guinea pigs upon acute inhalation of cotton dust. $A m \mathcal{F}$ Respir Cell Mol Biol 1991;5:93-8.

30 Piguet PF, Collart MA, Grau GE, Sappino AP, Vassalli P. Requirement of tumour necrosis factor for the development of silica-induced pulmonary fibrosis. Nature 1990; 344:245-7.

31 Adi S, Pollock AS, Shigenage JK, Moser AH, Feingold KR Grunfeld C. Role for monokines in the metabolic effects of endotoxin. Interferon-gamma restores responsiveness of $\mathrm{C} 3 \mathrm{H} / \mathrm{HEJ}$ mice in vivo. $\mathcal{F}$ Clin Invest 1992;89:1603-9.

32 Figari IS, Palladino MA. Stimulation of neutrophil chemo- taxis by recombinant tumor necrosis factor alpha and beta [abstract]. Fed Proc 1987;46:562.

33 Stephens K, Ishizaka A, Basilico L, Larrick J, Raffin T. Human tumor necrosis factor inhibits neutrophil chemotaxis [abstract]. Am Rev Respir Dis 1987;135(suppl): A338.

34 Nelson S, Bagby GJ, Bainton BG, Wilson LA, Thompson JJ, Summer WR. Compartmentalization of intraalveola and systemic lipopolysaccharide-induced tumor necrosis factor and the pulmonary inflammatory response. $\mathcal{F}$ Infect Dis 1989;159:189-94.

35 Corey P, Hutcheon M, Broder I, Mintz S. Grain elevator workers show work-related pulmonary function changes workers show work-related pulmonary function changes and dose-effect relation

36 Distefano A, Maestrelli P, Roggeri A, Turato G, Calabro S, Potena A. Up-regulation of adhesion molecules in the bronchial mucosa of subjects with chronic obstructive bronchitis. Am ₹ Respir Cell Mol Biol 1994;149:803-10.

37 Tosi MF, Stark JM, Smith CW, Hamedani A, Gruenert DC, Infeld MD. Induction of ICAM-1 expression on human airway epithelial cells by inflammatory cytokines-effects on neutrophil-epithelial cell adhesion. Am 7 Respir Cell Mol Biol 1992;7:214-21.

38 Sam Mugier MP, Roggeri A, et al. Airway eosinophilia in chronic bronchitis during exacerbations. Am $\Im$ Respir Crit Care bronchitis during exace

39 Flory CM, Jones ML, Miller BF, Warren JS. Regulatory roles of tumor necrosis factor-alpha and interleukin-1beta in monocyte chemoattractant protein-1-mediated pulmonary granuloma formation in the rat. $\mathrm{Am} \mathrm{f}$ Pathol 1995;146:450-62.

\section{Instructions to authors}

Three copies of all submissions should be sent to: The Editor, Occupational and Environmental Medicine, BMJ Publishing Group, BMA House, Tavistock Square, London WC1H 9JR, UK. All authors should sign the covering letter as evidence of consent to publication. Papers reporting results of studies on human subjects must be accompanied by a statement that the subjects gave written, informed consent and by evidence of approval from the appropriate ethics committee. These papers should conform to the principles outlined in the Declaration of Helsinki (BMf 1964; ii:177).
If requested, authors shall produce the data on which the manuscript is based, for examination by the Editor.

Authors are asked to submit with their manuscript the names and addresses of three people who they consider would be suitable independent reviewers. They will not necessarily be approached to review the paper.

Papers should include a structured abstract of not more than 300 words, under headings of Objectives, Methods, Results, and Conclusions. Please include up to three keywords or key terms to assist with indexing. 